\title{
Sistem Informasi Geografis Rekomendasi Objek Wisata Bali Menggunakan Metode TOPSIS
}

\author{
Ni Ketut Pradani Gayatri S, Dwi Putra Githa, I Putu Arya Dharmaadi \\ Program Studi Teknologi Informasi, Fakultas Teknik, Universitas Udayana \\ Bukit Jimbaran, Bali, Indonesia, telp. (0361) 701806 \\ e-mail: pradanigayatris@gmail.com, dwiputragitha@gmail.com, aryadharmaadi@yahoo.com
}

\begin{abstract}
Abstrak
Informasi merupakan aspek penting penunjang pariwisata di Bali. Informasi yang kurang lengkap terkait objek wisata seperti lokasi, budget, waktu menjadi masalah yang sering dialami wisatawan. Permasalahan tersebut dapat diatasi dengan menggabungkan sistem informasi geografis dan sistem pendukung keputusan. Sistem informasi geografis dapat memberikan tampilan maps secara dinamis dan sistem pendukung keputusan dapat memberikan rekomendasi objek wisata. Metode TOPSIS digunakan dalam mencari objek wisata yang paling sesuai dengan 3 jenis kriteria yaitu budget, waktu dan rating. Sistem informasi geografis rekomendasi objek wisata bertujuan untuk memberikan informasi terkait objek wisata. Sistem ini memberikan rekomendasi objek wisata maupun paket wisata yang dijadikan acuan oleh wisatawan yang akan berkunjung ke Bali. Hasil dari sistem informasi geografis adalah informasi objek wisata, rute perjalanan, rekomendasi objek wisata dan rekomendasi paket wisata. Hasil evaluasi kepuasan pengguna untuk aspek tampilan sistem 83,67\%, aspek kualitas sistem 84,33\%, aspek kualitas informasi 82,67\% dan aspek fungsionalitas sistem 85,67\%.
\end{abstract}

Kata Kunci: Sistem Informasi Geografis, Sistem Pendukung Keputusan, Metode TOPSIS.

Abstract
Information is important aspect which supported tourism in Bali. The problem experienced by tourists visiting Bali is lack information of tourist attraction such as location, budget, time and etc. It can be solved by combining geographic information system and decision support system. Geographic information system can provide maps and decision support system can provide recommendation of a tourist attraction. TOPSIS method is used to find the most suitable tourist attraction within the three criteria such as budget, time and rating. This system aimed to provide information related to tourist attraction, tourist attraction and tour package recommendation that can be used as a reference by tourist. The results of this system are tourist attraction information, travel routes, tourist recommendations and tour package recommendations. The results user satisfaction evaluation for aspects of the system view $83.67 \%$, aspects of system quality $84.33 \%$, aspects of information quality $82.67 \%$ and aspects of system functionality $85.67 \%$.

Keywords: Geographic Information System, Decision Support System, TOPSIS Method.

\section{Pendahuluan}

Bali merupakan salah satu tujuan wisata yang terkenal dikalangan wisatawan lokal maupun mancanegara. Keindahan alam, keunikan budaya dan tradisi menjadi daya tarik bagi para wisatawan untuk berkunjung ke Bali [1]. Kurangnya informasi mengenai tata letak objek wisata menjadi salah satu masalah yang sering dihadapi para wisatawan yang berkunjung ke Bali. Keterbatasan informasi mengenai harga tiket, waktu tempuh, popularitas dan informasi penting lainnya menjadi masalah lain yang dihadapi wisatawan. Masalah ini menyulitkan para wisatawan terutama yang baru pertama kali mengunjungi Bali dalam memperkirakan budget dan waktu yang dibutuhkan.

Pencarian informasi objek wisata dapat memanfaatkan tekonologi informasi. Teknologi dapat mempermudah akses informasi salah satunya dengan menggunakan dua sistem yaitu sistem informasi geografis dan sistem pendukung keputusan. Sistem informasi geografis dapat memberikan informasi tata letak objek wisata dalam bentuk digital maps. Sistem pendukung 
keputusan dapat menghasilkan rekomendasi objek wisata atau paket wisata yang dapat digunakan sebegai acuan bagi wisatawan untuk menentukan objek wisata yang akan dikunjungi.

Metode pengambilan keputusan yang digunakan dalam pencarian rekomendasi objek wisata dan paket wisata adalah metode TOPSIS. Metode TOPSIS digunakan oleh Gusti Ayu Made Shinta Witmasari dalam penelitiannya yang berjudul "Multi-Attribute Decision Making Scholarship Selection Using A Modified Fuzzy TOPSIS" dalam menentukan penerima beasiswa yang tepat berdasarkan kriteria kartu hasil studi, pendapatan orang tua, penggunaan listrik dan keaktifan mahasiswa kemudian penelitian yang dilakukan oleh Andi Sumardi yang berjudul "Pemilihan Tempat Wisata di Ternate dengan Metode Technique Order Preference by Similarity to Ideal Solution (TOPSIS) " menyatakan metode TOPSIS dapat memberikan rekomendasi tempat wisata yang dapat dikunjungi wisatawan [2,3]. Penelitian lain yang ditulis oleh Mehmet Oguzhan Ilban dan Hasan Huseyin Yildirim yang berjudul "Determination of Tourism Activities of the Wolrd Best Tourism Destinations Using the Muti-Criteria-Decision-Making Method" menyatakan hasil perhitungan metode TOPSIS akurat dalam meranking 15 tujuan wisata di dunia [4]. Penelitian terkait sistem informasi geografis yaitu "Design and Implementation of Geographic Information System on Tourism Guide Using Web-Based Google Maps" yang ditulis oleh Agus Sudarma, menyatakan bahwa sistem informasi geografis dapat memberikan informasi secara real time dibandingkan media informasi tradisional seperti brosur, pamflet, billboard kemudian penelitian yang ditulis oleh Gde Wahyu M Gunadi yang berjudul "Web-Based GIS using Spatial Decision Support System (SDSS) Concept for Searching Commercial Marketplace - Using Google Maps APl' menggunakan teknologi web-based GIS dengan memanfaatkan Google Maps API untuk menampilkan sebuah maps lokasi usaha [5]-[6].

Mengacu pada penelitian sebelumnya, pengembangan yang dilakukan pada penelitian mengenai Sistem Informasi Geografis Rekomendasi Objek Wisata di Bali adalah memadukan dengan Sistem Pendukung Keputusan (SPK) yang berfungsi untuk membantu wisatawan dalam pengambilan keputusan objek wisata mana yang dituju. Kelebihan dari sistem ini yaitu mampu menghasilkan rekomendasi objek wisata dan rekomendasi paket wisata sesuai dengan kriteria yang di-input-kan oleh user. Kriteria yang di-input-kan adalah jenis wisata, budget, waktu dan rating. Sistem informasi rekomendasi objek wisata memudahkan para wisatawan terutama yang pertama kali berkunjung ke Bali dalam menentukan objek wisata mana saja yang dapat dikunjungi.

\section{Metodologi Penelitian}

Alur penelitian Sistem Informasi Geografis Rekomendasi Objek Wisata di Bali ditunjukkan pada Gambar 1.



Gambar 1. Alur Penelitian Sistem Informasi Geografis Rekomendasi Objek Wisata di Bali

Alur penelitian dimulai dari melakukan studi literatur untuk mendapatkan teori-teori penunjang sehingga mendapatkan metode yang digunakan yaitu metode TOPSIS. Pendefisian manfaat, tujuan dan batasan masalah sistem digunakan untuk menentukan kriteria penting yang digunakan untuk mencari rekomendasi objek wisata. Pemodelan sistem dalam bentuk diagram konteks dan diagram alir, perancangan database, pemrograman sistem, pengujian sistem dan pembuatan laporan akhir 


\subsection{Gambaran Umum Sistem}

Gambaran umum dari Sistem Inforrmasi Geografis Rekomendasi Objek Wisata di Bali ditunjukkan pada Gambar 2.

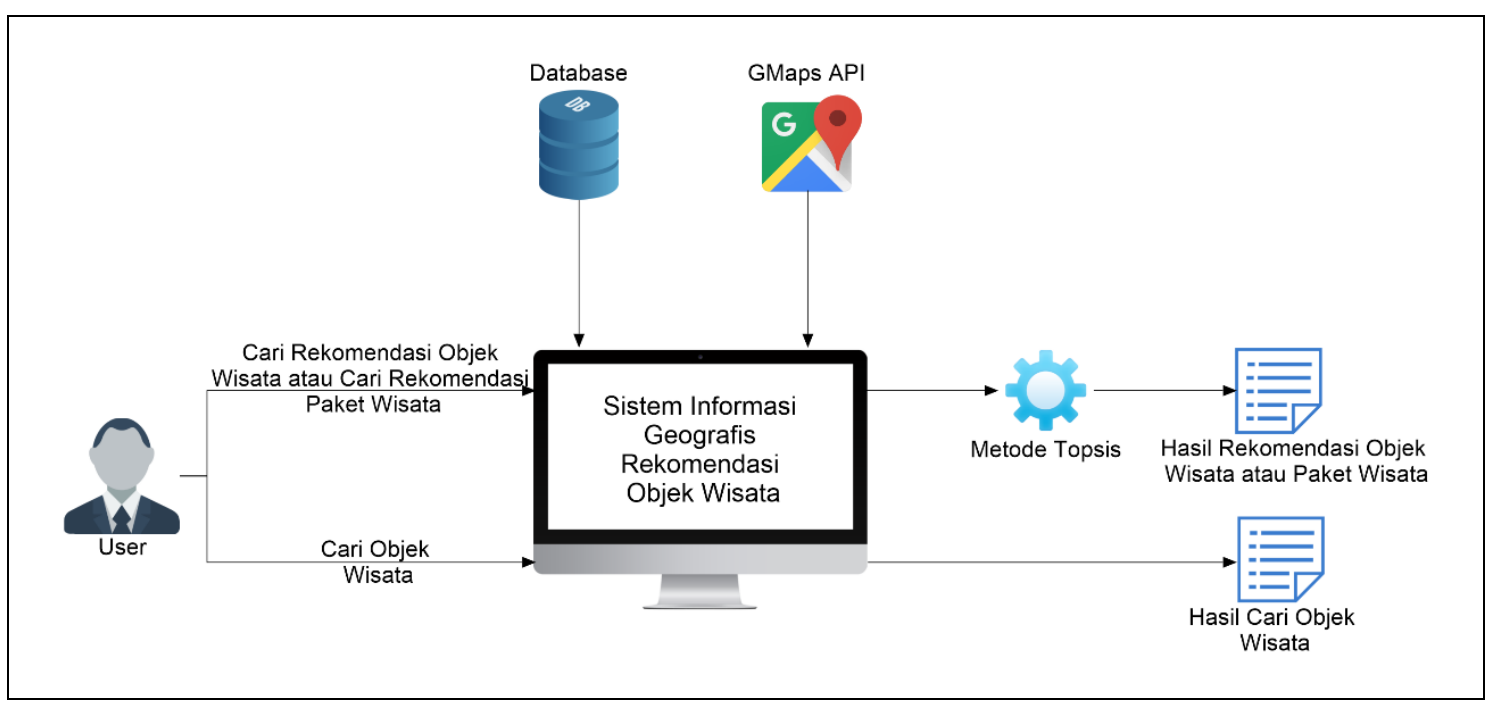

Gambar 2. Gambaran Umum Sistem Informasi Geografis Rekomendasi Objek Wisata di Bali

Sistem informasi rekomendasi objek wisata dirancang berbasis web dan diakses secara online. Menu utama yang terdapat pada sistem informasi rekomendasi objek wisata adalah cari objek wisata dan cari rekomendasi objek wisata atau paket wisata. Pengguna yang ingin mencari informasi objek wisata dapat meng-input-kan nama objek wisata yang diinginkan pada kolom search maka akan ditampilkan marker objek wisata pada maps beserta informasi objek wisata tersebut. Pengguna yang ingin mencari rekomendasi objek wisata atau paket wisata harus mengisi form yang berisi beberapa kriteria yaitu jenis wisata, budget, waktu, rating dan bobot dari masing-masing kriteria. Hasil data yang dimasukkan oleh pengguna akan di-filter kemudian dihitung dengan menggunakan metode TOPSIS yang akan menghasilkan rekomendasi objek wisata atau paket wisata.

\section{Kajian Pustaka}

Kajian pustaka berisi teori mengenai teknologi yang merupakan teori pendukung yang menjadi landasan teori untuk pemecahan masalah dari penelitian Sistem Informasi Geografis Rekomendasi Objek Wisata Bali menggunakan Metode TOPSIS.

\subsection{Sistem Informasi Geografis}

Sistem informasi geografis merupakan sistem yang mengelola data spasial. Informasi yang ditampilkan pada sistem informasi geografis dalam bentuk grafis menggunakan peta sebagai interface atau antar muka [7]. Konsep sistem informasi geografis terdiri dari beberapa layer dan relasi. Sistem informasi geografis berfungsi memberikan infromasi dan menganalisis data spasial. Fungsi lainnya dari sistem informasi geografis adalah untuk analisis penetapan database keruangan sehingga berdampak pada proses pengambilan keputusan [8].

\subsection{Google Maps dan Google Maps API}

Google maps merupakan peta virtual yang disajikan oleh google secara gratis. Layanan yang diberikan google maps yaitu menampilkan jalan-jalan diseluruh dunia, selain itu dapat menampilkan bentuk foto satelit. Google maps layaknya peta umum namun hanya menunjukkan jalan tanpa ada gunung, sungai atau batas daerah. Peta yang ada pada google maps sangat lengkap karena menampilkan nama jalan dan gedung [9]. Google Maps API merupakan fungsi yang diberikan google maps untuk membangun aplikasi berbasis web atau mobile. Fungsi dari Goole Maps API ini yaitu menampilkan lokasi pada maps, menunjukkan beberapa rute yang berbeda di maps. Fungsi lainnya adalah pemetaan distribusi data dan penentuan koordinat secara real time [10]. 


\subsection{Sistem Pendukung Keputusan}

Sistem pendukung keputusan merupakan sistem yang digunakan untuk membantu dalam pengambilan suatu keputusan. Sistem pendukung keputusan biasanya digunakan untuk situasi yang tidak terstruktur dan tidak pasti keputusan yang harus dibuat. Tujuan dari sistem pendukung keputusan memberikan informasi dan prediksi yang dapat dijadikan sebagai acuan agar pengambilan keputusan berjalan lebih baik. Sistem pendukung keputusan bermanfaat untuk memecahkan masalah yang kompleks, menghasilkan olusi yang cepat dan memperluas kemampuan dalam pengambilan keputusan [11].

\subsection{Metode TOPSIS}

Metode TOPSIS merupakan metode yang menghasilkan aternatif terbaik karena memiliki jarak terdekat dari solusi ideal positif dan jarak terjauh dari solusi ideal negatif [12]. Tahapantahapan perhitungan metode TOPSIS sebagai berikut.

1. Membangun Sebuah Matriks Keputusan

Matriks keputusan $X$ mengacu terhadap $m$ alternatif yang akan dievaluasi berdasarkan $n$ kriteria. Matriks keputusan $X$ dapat dilihat sebagai berikut.

\begin{tabular}{|c|c|c|c|c|c|}
\hline$x_{1}$ & $x_{2}$ & $x_{3}$ & $\ldots$ & $x_{n}$ & \\
\hline$a_{1}$ & $x_{11}$ & $x_{12}$ & $x_{31}$ & $\ldots$ & $x_{n 1}$ \\
\hline$a_{2}$ & $x_{12}$ & $x_{22}$ & $x_{32}$ & $\cdots$ & $x_{n 2}$ \\
\hline $\begin{array}{c}=a_{3} \\
\vdots\end{array}$ & $\begin{array}{c}x_{13} \\
\vdots\end{array}$ & $\begin{array}{c}x_{32} \\
\vdots\end{array}$ & $\begin{array}{c}x_{33} \\
\vdots\end{array}$ & $\begin{array}{l}\ldots \\
\ldots\end{array}$ & $\begin{array}{c}x_{n 3} \\
\vdots\end{array}$ \\
\hline$a_{m}$ & $x_{m 1}$ & $x_{m 2}$ & $x_{m 3}$ & $\ldots$ & $x_{m r}$ \\
\hline
\end{tabular}

2. Membuat Matriks Keputusan yang Ternormalisasi

Persamaan yang digunakan untuk mentransformasikan setiap elemen $x_{i j}$ sebagai berikut.

$r_{i j}=\frac{x_{i j}}{\sqrt{\sum_{i=1}^{m} x_{i j}^{2}}}$

3. Membuat Matriks Keputusan yang Ternormalisasi Tebobot

Dengan bobot $w_{j}=\left(w_{1}, w_{2}, w_{3}, \ldots, w_{n}\right)$, dimana adalah bobot dari kriteria ke-j dan $\sum_{j=1}^{n} w_{j}=1$, maka normalisasi bobot matriks $V$ sebagai berikut.

$v_{i j}=w_{j} r_{i j}$

4. Menentukan Matriks Solusi Ideal Positif dan Solusi Ideal Negatif

Solusi ideal positif dinotasikan $A^{+}$, sedangkan solusi ideal negatif dinotasikan $A^{-}$. Berikut ini adalah persamaan dari $A^{+}$dan $A^{-}$.

$A^{+}=\left\{\left(\max v_{i j} \mid j \in J\right), \quad\left(\min v_{i j} \mid j \in J^{\prime}\right), i=1,2,3, \ldots, m\right\}$

$A^{-}=\left\{\left(\min v_{i j} \mid j \in J\right), \quad\left(\max v_{i j} \mid j \in J^{\prime}\right), i=1,2,3, \ldots, m\right\}$

5. Menghitung Jarak Alternatif untuk Setiap Alternatif terhadap Solusi Ideal Positif $\left(s_{i}^{+}\right)$dan Solusi Ideal Negatif $\left(s_{i}^{-}\right)$

$S^{+}$adalah jarak alternatif dari solusi ideal positif didefinisikan sebagai berikut.

$s_{i}^{+}=\sqrt{\sum_{j=1}^{n}\left(v_{i j}-v_{j}^{+}\right)^{2}}$, dengan $i=1,2,3, \ldots, m$

$S^{-}$adalah jarak alternatif dari solusi ideal negatif didefinisikan sebagai berikut.

$s_{i}^{-}=\sqrt{\sum_{j=i}^{n}\left(v_{i j}-v_{j}^{-}\right)^{2}}$, dengan $i=1,2,3, \ldots, m$

6. Menghitung Nilai Preferensi Setiap Alternatif

Nilai preferensi dari setiap alternatif berdasarkan jarak positif dan negatif yang dimiliki masing-masing alternatif dapat dihitung dengan menggunakan persamaan berikut.

$C_{i}=\frac{s_{i}^{-}}{\left(s_{i}^{-}+s_{i}^{+}\right)}, 0 \leq C_{i} \leq 1$, dengan $i=1,2,3, \ldots, m$ 


\section{Hasil dan Pembahasan} berikut.

Hasil uji coba sistem informasi geografis rekomendasi objek wisata di Bali sebagai

\subsection{Uji Coba Tampilan Sistem Informasi Geografis}

Uji coba tampilan sistem informasi geografis rekomendasi objek wisata dijelaskan pada sub bab ini dari fungsi pencarian objek wisata hingga pencarian rekomendasi objek wisata.
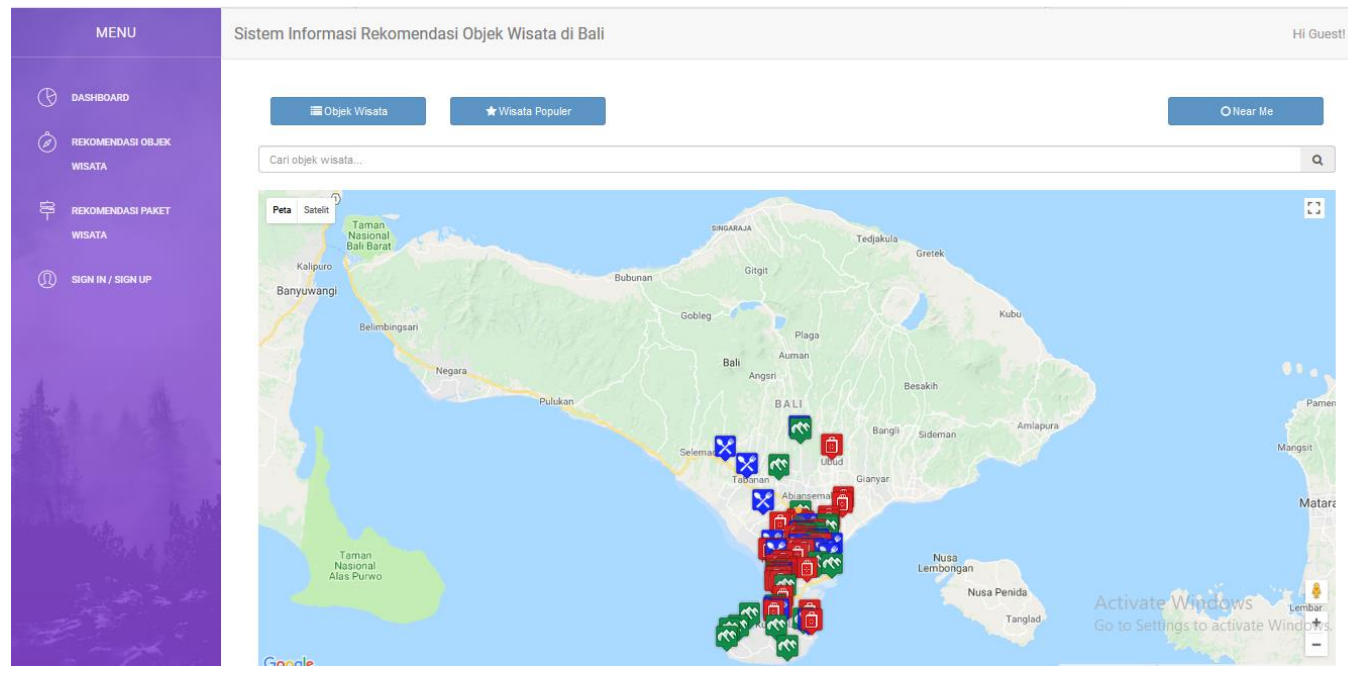

Gambar 3. Tampilan Halaman Awal

Gambar 3 menampilkan halaman awal atau dashboard pada sistem informasi geografis dimana terdapat marker pada maps yang menunjukkan objek wisata. Pengguna dapat melihat detail informasi objek wisata dengan mengklik salah satu marker yang ada pada maps.

\section{Gambar 4. Tampilan Search Objek Wisata}

Tampilan uji coba pencarian objek wisata ditunjukkan pada Gambar 4, dimana pengguna dapat mencari objek wisata yang diinginkan. Klik nama objek wisata yang dicari, maka akan muncul infowindow pada maps yang menampilkan detail informasi objek wisata tersebut. 

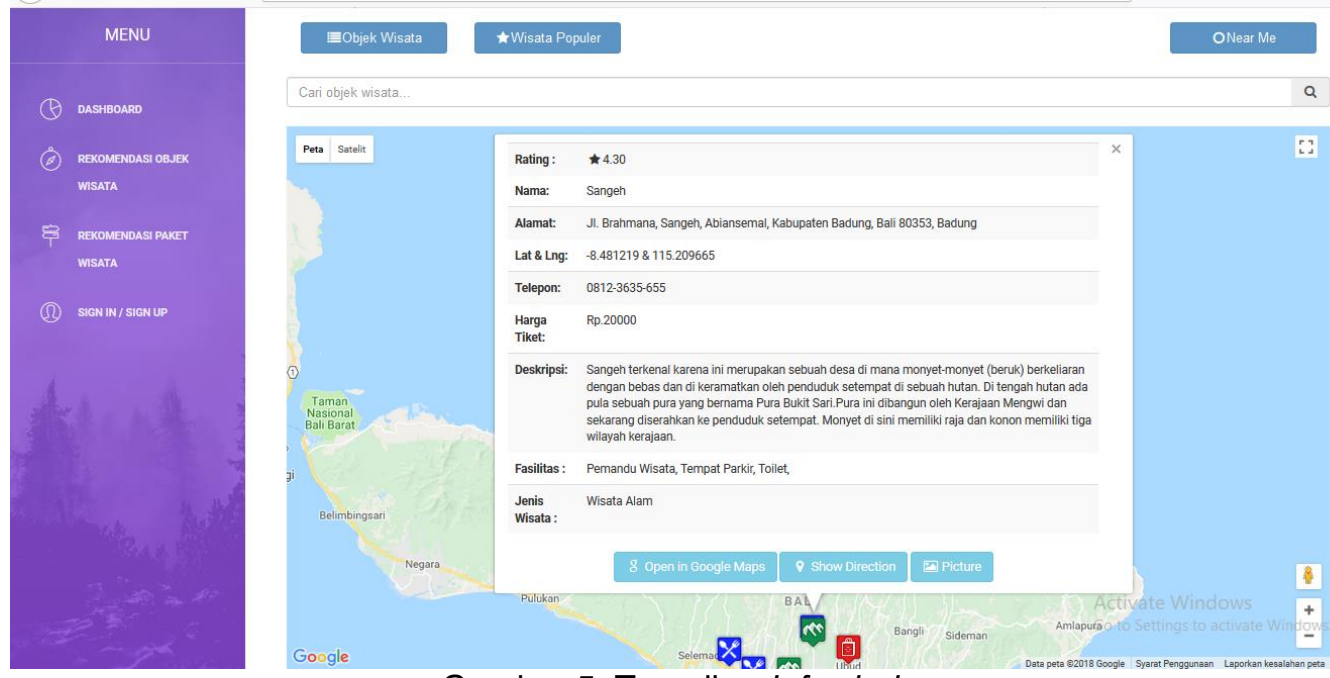

Gambar 5. Tampilan Infowindow

Gambar 5 menampilkan infowindow yang memuat detail informasi objek wisata. Pengguna dapat melihat rute perjalanan dari posisi pengguna menuju objek wisata yang dapat dilihat pada Gambar 6 .

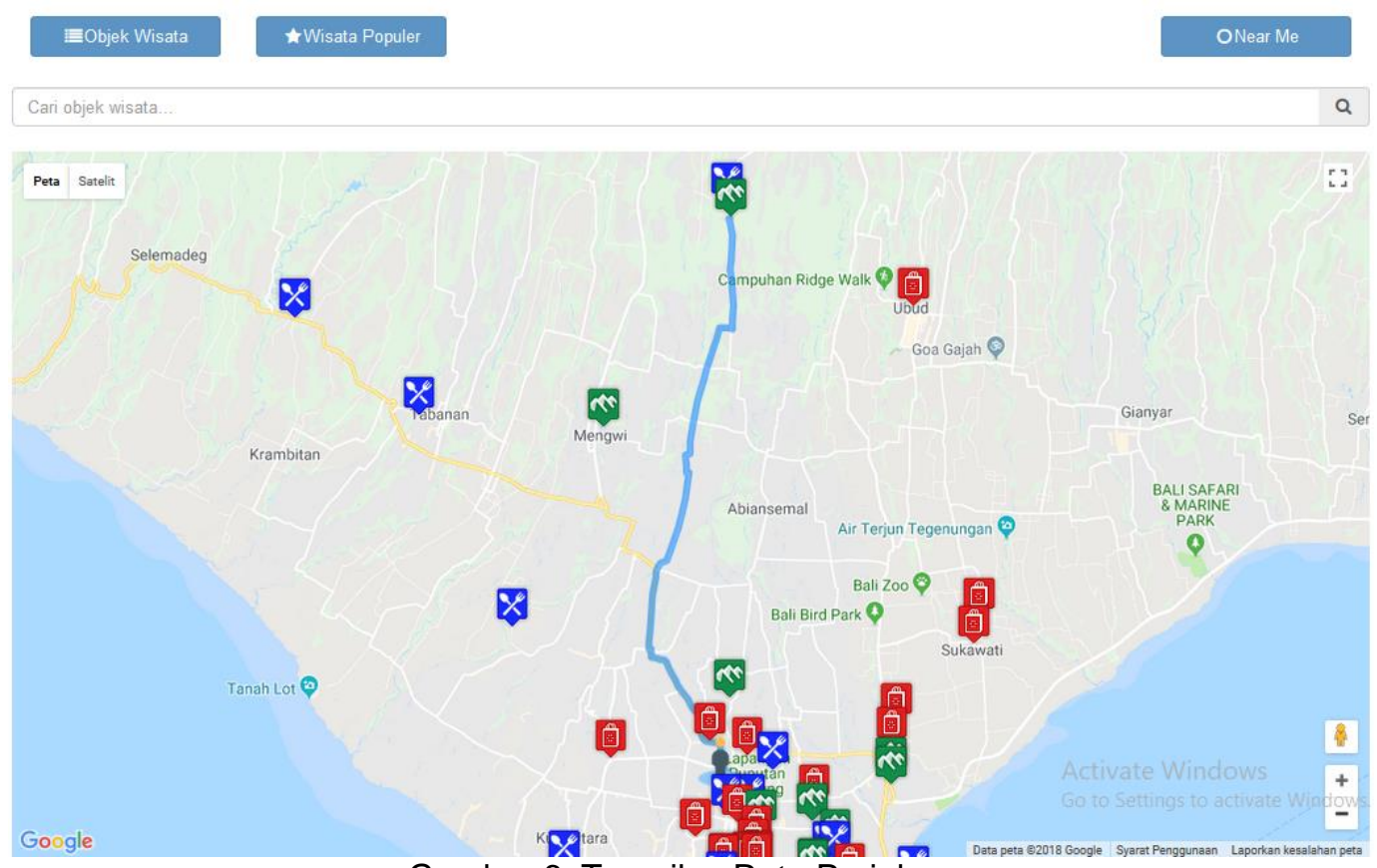

Gambar 6. Tampilan Rute Perjalanan

Rute perjalanan menuju objek wisata yang dipilih sesuai dengan moda transportasi yang dipilih ditunjukkan pada Gambar 6. Pengguna dapat mencari objek wisata yang terdekat dengan lokasi pengguna dengan fitur Near Me yang dapat dilihat pada Gambar 7. 

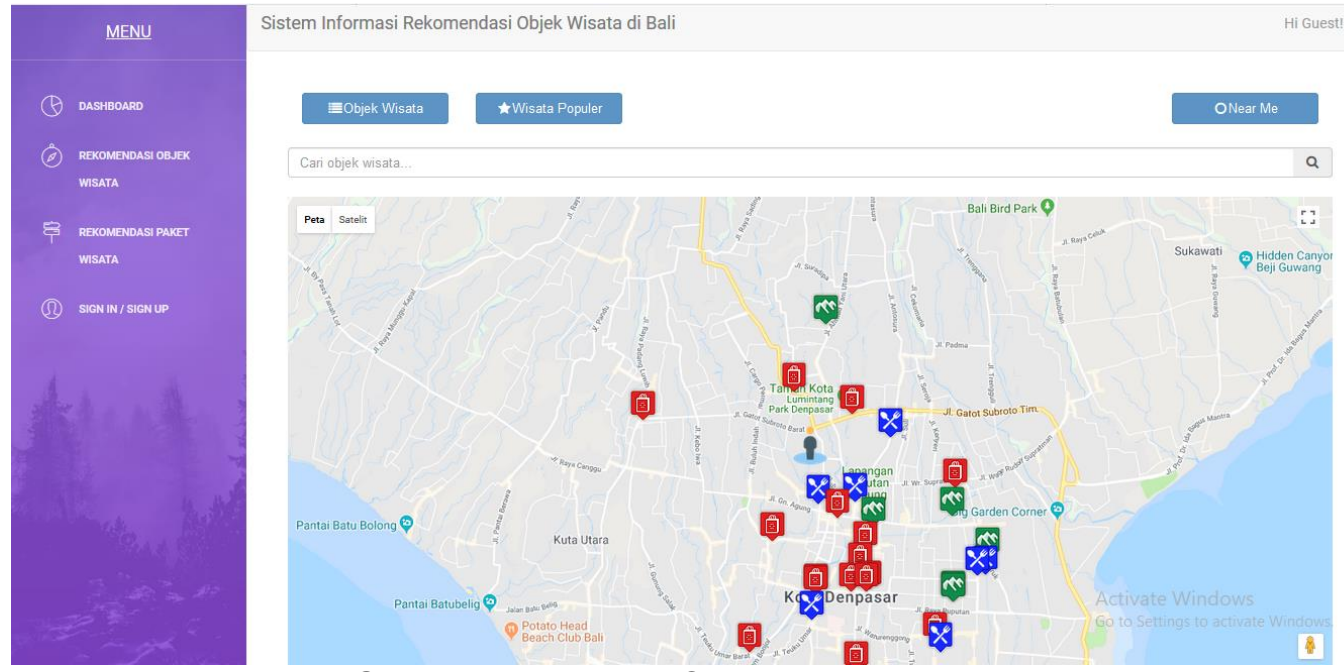

Gambar 7. Tampilan Objek Wisata Terdekat

Gambar 7 menampilkan objek wisata yang dekat dengan lokasi pengguna sesuai dengan radius yang sudah ditentukan yaitu $5 \mathrm{~km}$. Pengguna dapat mencari objek wisata populer yang dapat dilihat pada Gambar 8.



IAM BALI - 3D Museum \& Upside Down
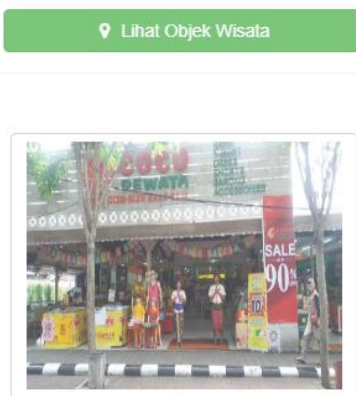

Coco Dewata Pusat Oleh Oleh - Lihat Objek Wisata

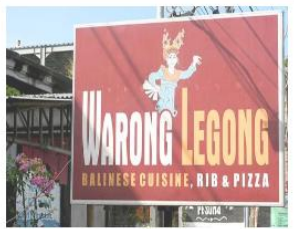

Warong Legong P Lhat Objek Wisata
Objek Wisata Alam Populer di Bali

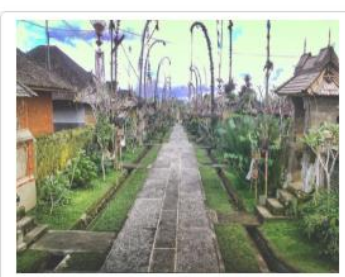

Desa Penglipuran

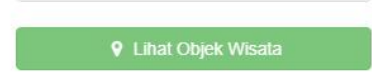

Objek Wisata Belanja Populer di Bali

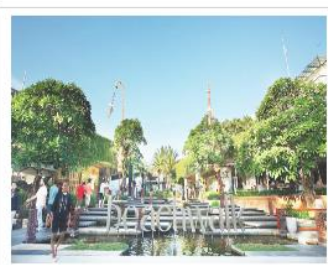

Beachwalk Shoping Center

9. Lihat Objek Wisata

objek Wisata Kuliner Populer di Bali



Warung Nasi Gonde Cik Swi

P Lihat Objek Wisala

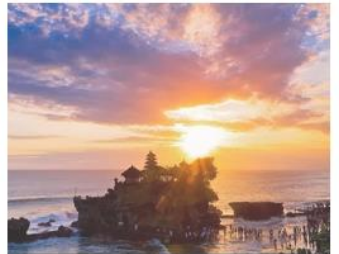

Pura Tanah Lot

Q Lihat Objek Wisata



Mall Bali Galeria P. Lihat Objek Wisata

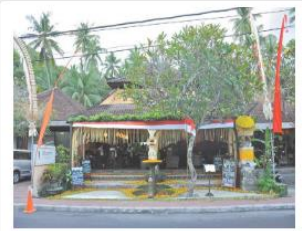

Vincents Restaurant

Q Lihat Objek Wisata

Gambar 8. Tampilan Objek Wisata Populer 
Objek wisata populer untuk masing-masing jenis objek wisata sesuai dengan rating tertinggi ditampilkan pada Gambar 8. Uji coba fitur pencarian rekomendasi objek wisata dapat dilihat pada Gambar 9.

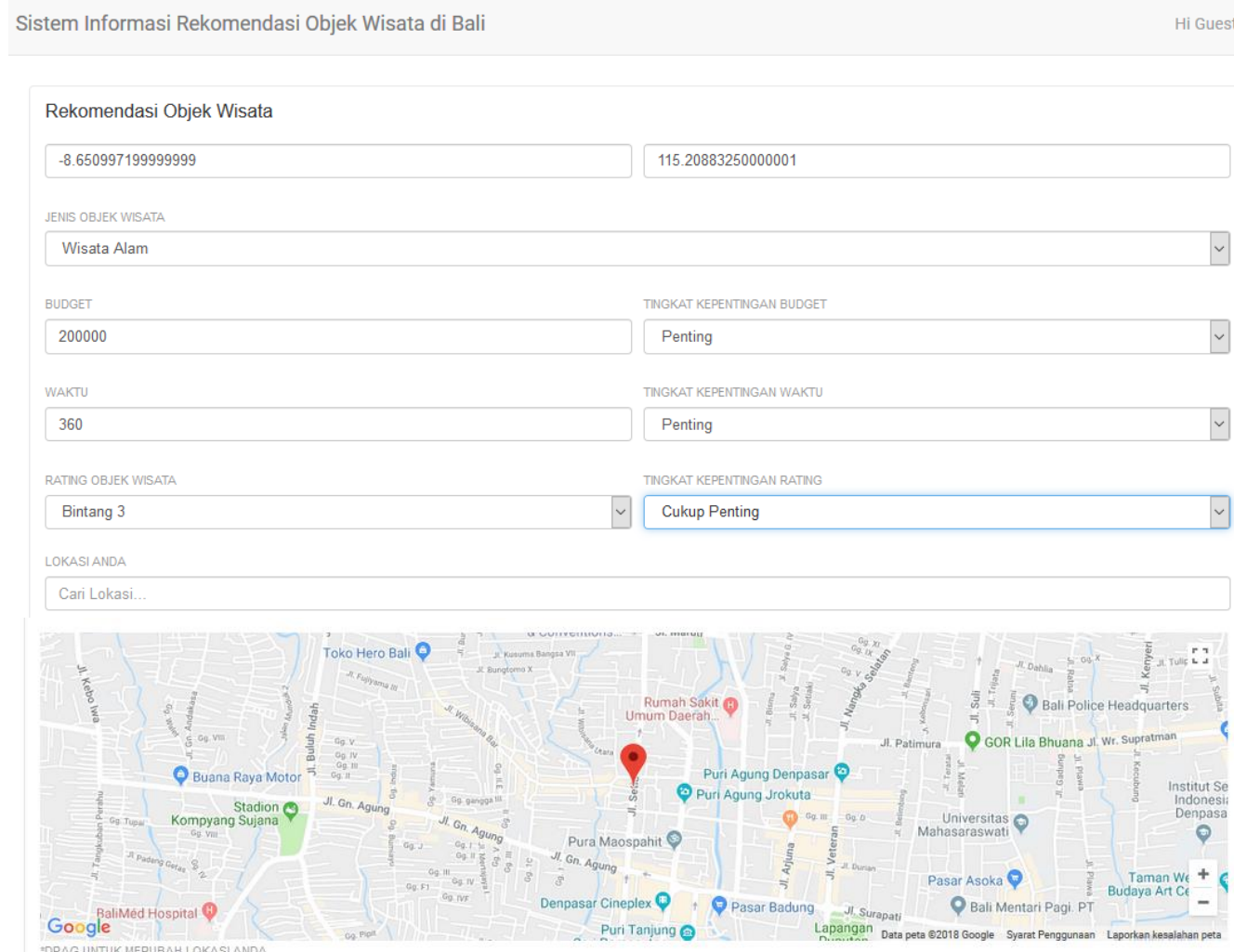

Gambar 9. Form Rekomendasi Objek Wisata

Gambar 9 menampilkan form rekomendasi objek wisata yang harus diisi oleh pengguna yang ingin mencari rekomendasi objek wisata. Form rekomendasi terdiri dari jenis wisata, budget, waktu dan rating, selain itu pengguna juga dapat menentukan lokasinya.

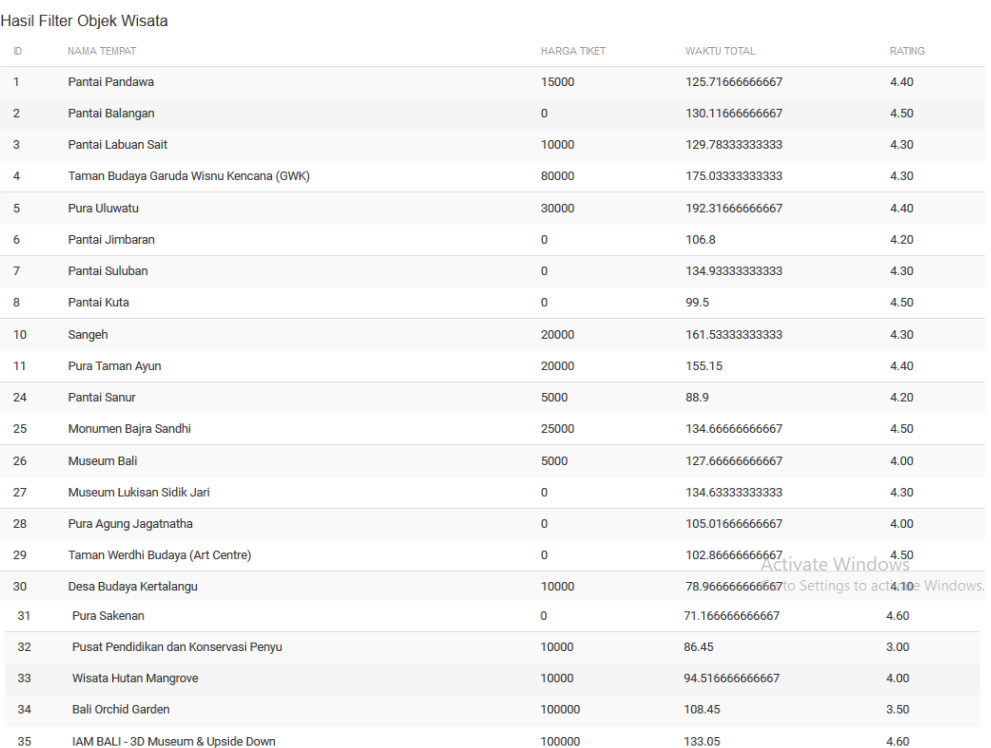

Gambar 10. Hasil Filter Objek Wisata 
Hasil filter data objek wisata yang sesuai dengan kriteria yang dimasukkan pengguna pada form rekomendasi objek wisata ditampilkan pada Gambar 10. Hasil filter data objek wisata kemudian dijadikan sebagai alternatif yang akan dihitung menggunakan metode TOPSIS untuk mendapatkan rekomendasi objek wisata.

\begin{tabular}{|c|c|c|c|c|}
\hline $\mathbb{D}$ & NAMA TEMPAT & HASIL MATRIKS BUDGET & HASIL MATRIKS WAKTU & HASIL MATRIKS RATING \\
\hline 1 & Pantai Pandawa & 0.087481776527971 & 0.21368659224297 & 0.2213348003672 \\
\hline 2 & Pantai Balangan & 0 & 0.22116548132585 & 0.22636513673918 \\
\hline 3 & Pantai Labuan Sait & 0.05832118435198 & 0.22059889881957 & 0.21630446399522 \\
\hline 4 & Taman Budaya Garuda Wisnu Kencana (GWK) & 0.46656947481584 & 0.29751247404689 & 0.21630446399522 \\
\hline 5 & Pura Uluwatu & 0.17496355305594 & 0.32688977699743 & 0.2213348003672 \\
\hline 6 & Pantai Jimbaran & 0 & 0.18153303501166 & 0.21127412762324 \\
\hline 7 & Pantai Suluban & 0 & 0.22935259854157 & 0.21630446399522 \\
\hline 8 & Pantai Kuta & 0 & 0.16912487812416 & 0.22636513673918 \\
\hline 10 & Sangeh & 0.11664236870396 & 0.2745658825426 & 0.21630446399522 \\
\hline 11 & Pura Taman Ayun & 0.11664236870396 & 0.26371582754737 & 0.2213348003672 \\
\hline 24 & Pantai Sanur & 0.02916059217599 & 0.1511075544245 & 0.21127412762324 \\
\hline 25 & Monumen Bajra Sandhi & 0.14580296087995 & 0.22889933253655 & 0.22636513673918 \\
\hline 26 & Museum Bali & 0.02916059217599 & 0.2170010999047 & 0.20121345487928 \\
\hline 27 & Museum Lukisan Sidik Jari & 0 & 0.22884267428592 & 0.21630446399522 \\
\hline 28 & Pura Agung Jagatnatha & 0 & 0.17850181860307 & 0.20121345487928 \\
\hline 29 & Taman Werdhi Budaya (Art Centre) & 0 & 0.17484736143757 & $\begin{array}{l}0.22636513673918 \\
\text { vate Windows }\end{array}$ \\
\hline 30 & Desa Budaya Kertalangu & 0.05832118435198 & 0.1342233957374 & $0.20624379125126 \mathrm{t}$ \\
\hline
\end{tabular}

Gambar 11. Hasil Matriks Keputusan Tenormalisasi

Gambar 11 menampilkan matriks keputusan ternormalisasi, dimana matriks keputusan ternormalisasi dihitung dengan cara membagi nilai kriteria pada masing-masing alternatif dengan nilai pembagi.

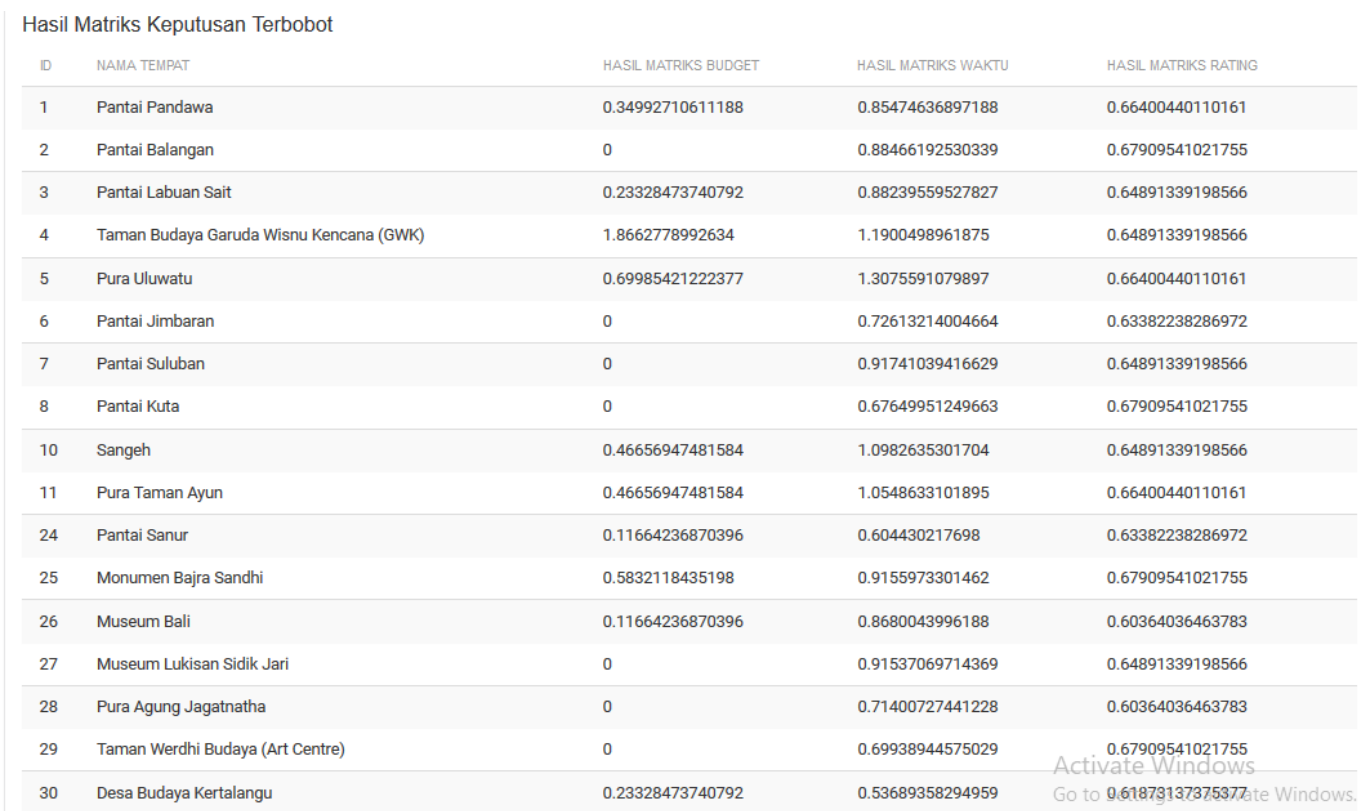

Gambar 12. Hasil Matriks Keputusan Tenormalisasi Terbobot

Matriks keputusan ternormalisasi terbobot ditampilkan pada Gambar 12. Matriks keputusan ternormalisasi terbobot dihitung dengan mengalikan matriks keputusan ternormalisasi dengan bobot masing-masing kriteria. 


\begin{tabular}{llll}
$\begin{array}{l}\text { Matriks Solusi Ideal } \\
\text { NAMA }\end{array}$ & HASIL MATRIKS BUDGET & HASIL MATRIKS WAKTU & HASLL MATRIKS RATNG \\
\hline Solusi Ideal Positif & 0 & 0.48386146036191 & 0.6941864193335 \\
Solusi Ideal Negatif & 2.3328473740792 & 1.3075591079897 & 0.45273027347837
\end{tabular}

Gambar 13. Hasil Matriks Solusi Ideal Positif dan Negatif

Gambar 13 menampilkan matriks solusi ideal positif dan negatif. Matriks solusi ideal positif untuk kriteria budget dan waktu didapatkan berdasarkan nilai minimum sedangkan kriteria rating berdasarkan nilai maksimum. Matriks solusi ideal negatif kriteria budget dan waktu didapatkan berdasarkan nilai maksimum sedangkan kriteria rating berdasarkan nilai minumum.

\begin{tabular}{|lll}
\hline Menghitung Kedekatan Terhadap Solusi Ideal Positif & \\
\hline 1 NaMA & Nura Sakenan & 1 \\
\hline 31 & Pantai Sanur & 0.9289808059096 \\
\hline 24 & Pantai Kuta & 0.92626286594433 \\
\hline 29 & Taman Werdhi Budaya (Art Centre) & 0.91808249085342 \\
\hline 28 & Pura Agung Jagatnatha & 0.906996266216 \\
\hline 6 & Pantai Jimbaran & 0.90616093492393 \\
\hline 30 & Desa Budaya Kertalangu & 0.8993985511388 \\
\hline 33 & Wisata Hutan Mangrove & 0.88164219059404 \\
\hline 32 & Pusat Pendidikan dan Konservasi Penyu & 0.86329889566224 \\
\hline 2 & Pantai Balangan & 0.85586682018567 \\
\hline 26 & Museum Bali & 0.84620602590249 \\
\hline 27 & Museum Lukisan Sidik Jari & 0.84546219181111 \\
\hline 7 & Pantai Suluban & 0.84483318090276 \\
\hline 3 & Pantai Labuan Sait & 0.82257017504809 \\
\hline 1 & Pantai Pandawa & 0.80013399957562 \\
\hline 11 & Pura Taman Ayun & 0.71972480790759 \\
\hline 25 & Monumen Bajra Sandhi & 0.71347134159305 Settings to activate Windows. \\
\hline
\end{tabular}

Gambar 14. Hasil Perankingan Alternatif Objek Wisata

Hasil perankingan alternatif dihitung terhadap nilai matriks solusi ideal positif dan negatif ditampilkan pada Gambar 14. Alternatif objek wisata kemudian diurutkan dari nilai preferensi terbesar ke terkecil.

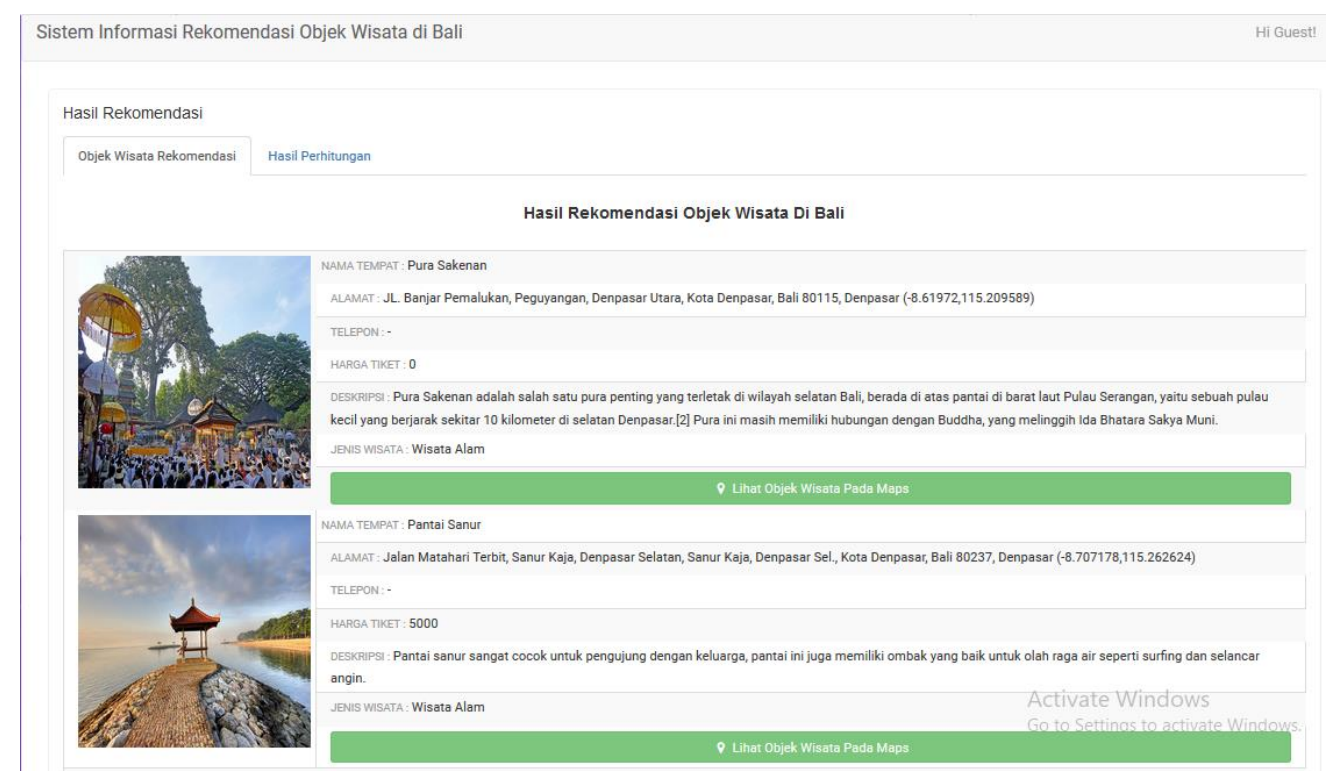



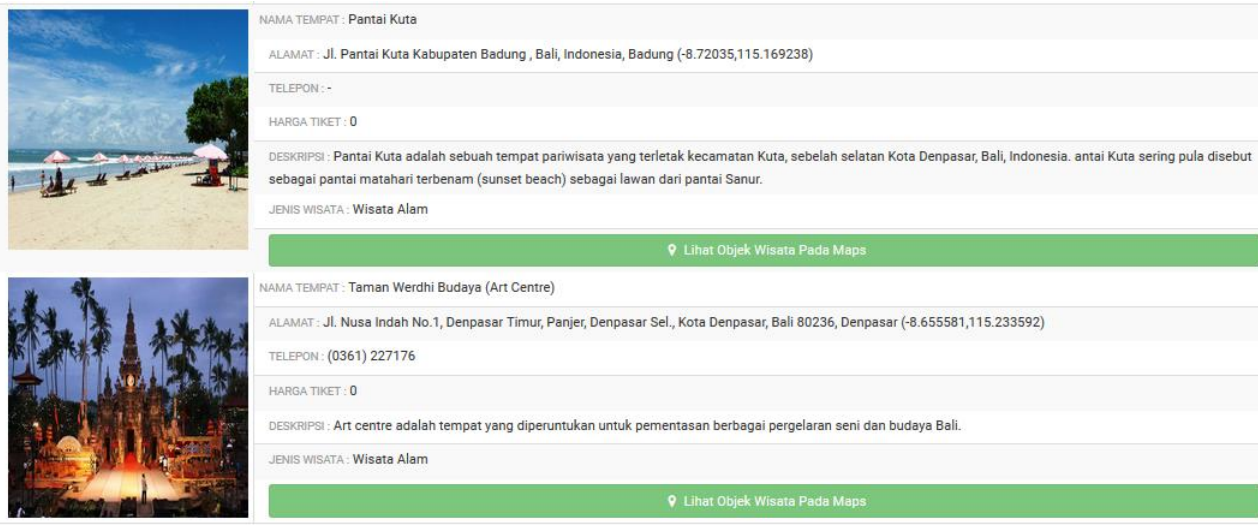

Gambar 15. Hasil Rekomendasi Objek Wisata

Gambar 15 menampilkan hasil rekomendasi objek wisata yang dihasilkan melalui perhitungan metode TOPSIS sesuai dengan kriteria yang dimasukkan pengguna pada form rekomendasi objek wisata. Hasil rekomendasi objek wisata yang ditampilkan adalah hanya 5 peringkat teratas dari 22 alternatif yang digunakan.

\subsection{Hasil Evaluasi Kepuasan Pengguna}

Evaluasi kepuasan pengguna didapatkan melalui kuisioner yang diisi oleh 30 responden. Aspek yang dievaluasi adalah aspek tampilan sistem, aspek kualitas sistem, aspek kualitas informasi dan aspek fungsionalitas sistem. Contoh perhitungan skala likert untuk aspek fungsionalitas sistem sebagai berikut.

Tabel 1. Skor Likert untuk Aspek Fungsionalitas Sistem

\begin{tabular}{|c|l|l|l|l|l|l|}
\hline No & \multicolumn{1}{|c|}{ Pertanyaan } & STS & TS & RG & S & SS \\
\hline 1 & $\begin{array}{l}\text { Menu dan fitur yang terdapat pada } \\
\text { sistem bekerja dengan baik }\end{array}$ & - & 1 & - & 19 & 10 \\
\hline 2 & $\begin{array}{l}\text { Pengguna terbantu dengan } \\
\text { adanya sistem }\end{array}$ & - & - & - & 21 & 9 \\
\hline $\begin{array}{c}\text { Jumlah } \\
\text { Skor Likert } \\
\text { (jumlah responden*bobot nilai jawaban) }\end{array}$ & 0 & 2 & 0 & 160 & 95 \\
\hline $\begin{array}{l}\text { Total Skor Likert } \\
\text { (Skor likert STS+TS+RG+S+SS) }\end{array}$ & -257 & 1 & - & 40 & 19 \\
\hline
\end{tabular}

Total skor likert untuk aspek fungsionalitas sistem ditampilkan pada Tabel 1. Cara mencari persentase Indeks (\%) untuk menentukan interval akhir dari aspek penilaian sebagai berikut.

Indeks $(\%)=(257 / 300) * 100 \%$

Indeks $(\%)=85,67 \%$

Masing-masing aspek yang dievaluasi memiliki dua buah pertanyaa. Hasil evaluasi pengguna yang dihitung dengan menggunakan teknik skala likert dapat dilihat pada Tabel 2.

Tabel 2. Hasil Evaluasi Kepuasan Pengguna

\begin{tabular}{|l|c|}
\hline \multicolumn{1}{|c|}{ Aspek yang dinilai } & Persentase Skor \\
\hline Aspek tampilan sistem & $83,67 \%$ \\
\hline Aspek kualitas sistem & $84,33 \%$ \\
\hline
\end{tabular}




\begin{tabular}{|l|l|}
\hline Aspek kualitas informasi & $82,67 \%$ \\
\hline Aspek fungsionalitas sistem & $85,67 \%$ \\
\hline
\end{tabular}

Tabel 2 menampilkan hasil evaluasi pengguna terhadap sistem melalui 4 aspek yang diuji yaitu aspek tampilan, kualitas sistem, kualitas informasi dan fungsionalitas sistem. Presentase skor yang didapatkan masing-masing aspek melebihi angka $80 \%$ sehingga masuk dalam kategori sangat baik. Hasil evaluasi kepuasan pengguna tersebut menunjukkan bahwa tampilan sistem sudah baik dan menarik. Sistem juga mudah digunakan dan user friendly. Informasi yang dihasilkan sistem jelas dan sesuai dengan kebutuhan pengguna. Secara keseluruhan sistem informasi geografis rekomendasi objek wisata yang dibangun sudah bekerja dengan baik dan memudahkan pengguna dalam pencarian informasi mengenai objek wisata.

\section{Kesimpulan}

Sistem informasi geografis rekomendasi objek wisata yang dibangun mampu memanajemen data seperti input, edit dan delete data objek wisata maupun data user, melakukan pencarian objek wisata, menampilkan informasi objek wisata, menampilkan informasi objek wisata terdekat, menampilkan informasi objek wisata populer, menampilkan rute perjalanan dan memberikan rekomendasi objek wisata sesuai dengan kriteria yang dimasukkan oleh pengguna. Sistem informasi geografis rekomendasi objek wisata memudahkan pencarian informasi objek wisata dan rekomendasi objek wisata untuk pengguna, selain itu bermanfaat sebagai media promosi objek wisata yang ada di Bali.

\section{Daftar Pustaka}

[1] I. N. S. Paliwahet, I. M. Sukarsa and I. K. G Darma Putra, "Pencarian Informasi Wisata Daerah Bali menggunakan Teknologi Chatbot," Lontar Komputer, vol. 8 No. 3, pp. 144145, 2017.

[2] G. A. M. S. Wimatsari, I. K. G. Darma Putra and P. W. Buana, "Multi-Attribute Decision Making Scholarship Selection Using A Modified Fuzzy TOPSIS," International Journal of Computer Science Issues, vol. 10 No. 2, pp. 309-131, 2013.

[3] A. Sumardin, "Pemilihan Tempat Wisata di Ternate dengan Metode Technique Order Preference by Similarity to Ideal Solution (TOPSIS)," Inspiration, vol. 4 No. 1, pp. 25-32, 2014.

[4] M. O. Illban and H. H. Yildirim, "Determination of Tourism Activities of the World's Best Tourism Destinations using the Multi-Criteria Decision-Making Method," Cogent Social Science, pp. 8-16, 2017.

[5] A. Sudarma, I. N. Piarsa and P.W. Buana, "Design and Implementation of Geographic Information System on Tourism Guide using Web-Based Google Maps," International Journal of Computer Science Issues, vol. 10 No. 2, p. 476, 2013.

[6] G. W. M. Gunadi, I. N. Piarsa and A. A. K. Oka Sudana, "Web-Based GIS by using Spatial Decision Support System (SDSS) Concept for Searching Commercial Marketpace using Google Map API," International Journal of Computer Applications, vol. 50 No. 7, p. $1,2012$.

[7] E. Prahasta, Konsep-konsep Dasar Sistem Informasi Geografis, Bandung: Informatika, 2002.

[8] S. Rahayu, I. N. Piarsa and P. W. Buana, "Sistem Informasi Geografis Pemetaan Daerah Aliran Sungai Berbasis Web," Lontar Komputer, vol. 7 No. 2, pp. 75-76, 2016.

[9] Minarni and Y. F. Yusdi, "Sistem Informasi Geografis Pariwisata Kota Padang menggunakan Application Programming Interface (API) Google Maps Berbasis Web," Jurnal TEKNOIF, vol. 3 No. 1, p.33, 2015.

[10] A. Rahmi, I. N. Piarsa and P. W. Buana, "FinDoctor - Interactive Android Clinic Geographical Information System Using Firebase and Google Maps API," International Journal of New Technology and Research, vol. 3 No. 7, pp. 8-12, 2017.

[11] I. Hasan, Pokok-pokok Materi Teori Pengambilan Keputusan, Jakarta: Ghalia Indonesia, 2002.

[12] S. Kusumadewi, Fuzzy Multi-Attribute Decision Making (Fuzzy MADM), Yogyakarta: Graha Ilmu, 2006. 